\title{
POTENCIANT LA IMAGINACIÓ A TRAVÉS DE L'ACTIVITAT PLÀSTICA
}

\author{
Isabel Castilleja. Mestra del CEIP de Pràctiques de Tarragona
}

Penso que no és agosarat afirmar que l'educació plàstica proporciona un seguit d'experiències insubstituïbles als nostres alumnes, ja que és una eina que els permet percebre el seu entorn d'una forma distinta a l'habitual. L'expressió plàstica és un llenguatge, un mitjà de comunicació que els ajuda a expressar-se i a enriquir-se com a persones, desenvolupant-los una sensibilitat i una percepció diferent del món que els envolta. És un llenguatge que potencia la creativitat i la imaginació, i que els ajuda a exterioritzar les vivències d'una manera subjectiva. I a nosaltres, com a educadors i receptors del seu missatge, ens proporciona una informació molt valuosa per entendre el complex entramat interior dels infants.

És evident que tothom no dóna la mateixa importància a aquesta matèria, perquè mentre uns es lamenten de la poca preparació del professorat en aquest camp, altres dissenyen horaris curriculars on l'expressió plàstica només gaudeix d'una sessió setmanal: un horari irrisori quan s'ha d'exterioritzar tantes coses en un temps tan insuficient.

\section{Una altra visió de la plàstica}

És cert que, de vegades, els professionals ens limitem a l'ensenyament de tècniques i més tècniques (retallar, modelar, collage...), oblidant la importància que té la continuïtat del procés en la realització del treball plàstic. El fet d'haver d'esperar d'una setmana a l'altra per veure el resultat de l'esforç del nen pot desencadenar-li un avorriment i una desmotivació que alenteixi el ritme del treball i el porti, fins i tot, a no acabar-lo. Davant d'aquesta situació, que tantes vegades he experimentat, cal plantejarse que, malgrat tot, donar tècniques -i amb elles un seguit de recursos que els seran útils posteriorment, tant en la seva vida personal com escolar- és una forma de superar algunes deficiències. De passada, podran conèixer diferents materials i eines que els ajudaran a escollir, a curt i a llarg termini, la millor manera d'expressar les seves inquietuds plàstiques.

Tanmateix, com a educadors que som, hem de potenciar el desenvolupament de la capacitat creativa en tota la seva amplitud, fomentant uns resultats plàstics espontanis i sense deixar-los caure, als nens, en uns estereotips que els podrien fer dubtar de les seves destreses, i arribar, fins i tot, a infravalorar-se fins al punt d'etiquetar-se com "un manasses" o "un poca traça"... En definitiva, s'han de treballar implícitament valors com la confiança i la seguretat. Per tant, un objectiu primordial que ens hauríem de proposar és el de "facilitar a l'alumne l'adquisició d'un llenguatge plàstic personal", i donar-li recursos suficients perquè pugui experimentar per ell mateix, i eines que l'ajudin a exterioritzar les seves inquietuds mitjançant un món ple de sensibilitat, color i estètica.

Si volem uns nens oberts, segurs i confiats, la millor manera és que des de petits caminin sols, que creïn sols, i com que tot és imitable, oferirem exemples prou significatius per guiar-los en el procés d'aprenentatge, però mai per modelar-los. Així doncs, es tracta de potenciar en l'alumne el fet d'aprendre a veureles formes $\mathrm{i}$ la seva representació a l'espai, tot aprenent a observar de manera més sistematitzada a mesura que s'avança en les diferents etapes del procés educatiu (de $1 \mathrm{r}$ a 6 è).

A fi de comptes, la tasca de control del gest i l'adquisició de seguretat implica un primer pas important, on l'alumne s'ha de familiaritzar amb el material i les eines que utilitzarà en el seu treball plàstic. Així, les seves capacitats motrius progressaran amb una atenció continuada.

En un segon pas, el nen ha d'aconseguir el resultat plàstic que s'ha proposat fer, de forma que li resulti personal, creatiu, interessant i satisfactori. I nosaltres, com a docents, l'hem de valorar amb una actitud oberta, tenint en compte el seu esforç, imaginació $\mathrm{i}$ interès, amb independència del resultat plàstic obtingut.

Un aspecte molt important és la motivació del mestre a l'hora de plantejar el treball. L'exercici s'ha de presentar amb il-lusió, donant-li, fins i tot, un caire enigmàtic al possible resultat. Així serà més fàcil implicar l'alumne en allò que volem que aconsegueixi. Un exercici de retallar paper pot semblar, a primer cop d'ull, una tasca massa senzilla per a l'alumne, però serà una activitat $a$ tenir en compte a l'hora d'observar la contínua evolució dels nens en l'adquisició de destreses i habilitats manuals. Un treball plàstic molt satisfactori tant en el seu desenvolupament com en els resultats aconseguits, és el que a continuació es presenta. 


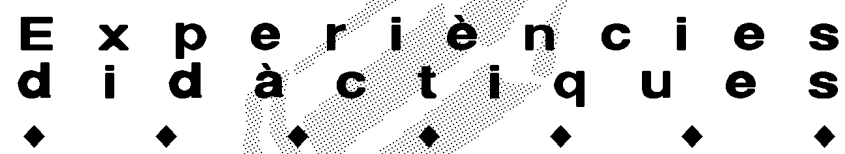

\section{Activitat concreta}

Els materials necessaris per al desenvolupament de l'activitat són a l'abast de tothom i es preparen ràpidament. Només cal que cada nen disposi d'un full de paper blanc, d'un quart de cartolina de color, tisores i goma d'enganxar.

Pel que fa al procediment a seguir, cal:

1) Doblegar el full blanc dues vegades, primer per la meitat i després per la meitat de la meitat. 2) Retallar formes diferents sobre el paper, sempre plegat (cercles, rombes, altres figures) i guardar tots els retalls, ja que després es faran servir. 3) Desplegar el paper per observar la simetria que ha sorgit, i enganxar el paper blanc a la part esquerra o dreta de la cartolina. 4) Amb tots el petits retalls guardats al punt 1 , construir qualsevol composició que el nen pugui imaginar.

\section{Dificultat de l'activitat}

La presentació del treball a fer tindrà certes variants, depenent del curs a treballar, ja que la dificultat s'ha d'adequar a les capacitats dels nens.

A primer i a segon curs cal fer, davant els alumnes, l'explicació del treball d'una manera pràctica, suggerint formes senzilles que es poden dibuixar prèviament a la pissarra (cercles, pals, animals...). Després se'ls convida que siguin ells els que retallin les formes a partir de les seves pròpies idees. El paper retallat es desplega per observar amb atenció les formes simètriques aconseguides d'una manera espontània. El resultat obtingut es comenta entre tots, buscant possibles significats imaginatius. Després s'enganxen les figures en una part de la cartolina, i és aquí on millor s'aprecia el resultat obtingut. El pas següent serà formar una composició amb els retalls sobrers, segons la imaginació i enginy de cada alumne.

A tercer i a quart l'explicació es farà més teòrica. Se'ls poden presentar treballs d'altres nens, fets amb la mateixa tècnica, comentant-los, parlant d'altres possibilitats i d'altres idees que, el grup, pugui suggerir. Els resultats plàstics acostumen a ser semblants als dels nens de primer i segon curs, però amb formes més elaborades, més petites, i amb temes més variats.

A cinquè i sisè, quan ja s'ha treballat els textos instructius en llengua, es pot aprofitar la circumstància $i$ presentar per escrit als alumnes les instruccions a seguir, i deixar que completin el treball de forma satisfactòria, tant pel que fa a la comprensió com a la creació pròpia. Potser els resultats ens sorprendran.

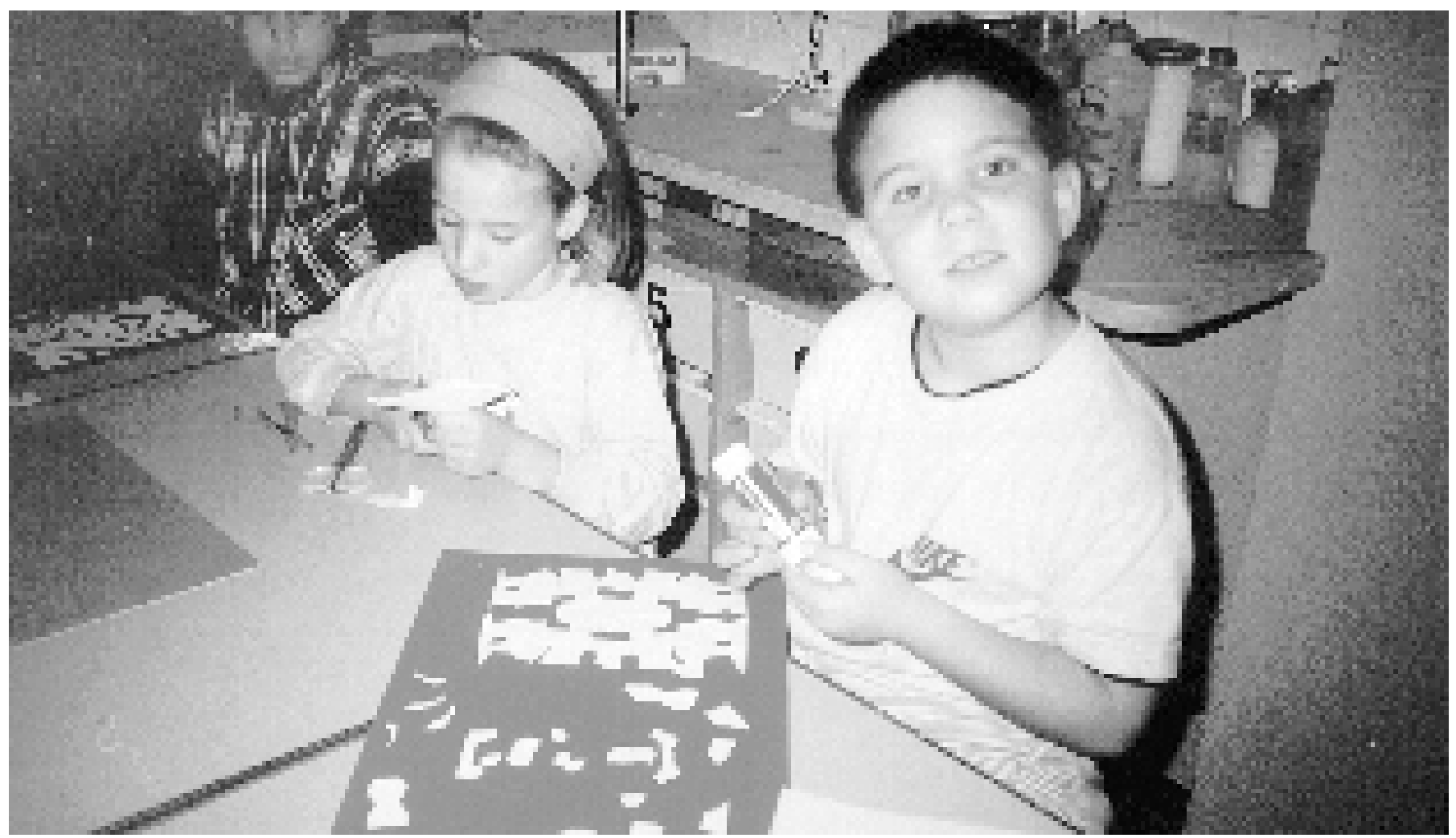

Alumnes de $1 r$ curs realitzant la seva composició plàstica. 